\title{
WestVirginiaUniversity
}

THE RESEARCH REPOSITORY @ WVU

Graduate Theses, Dissertations, and Problem Reports

2015

\section{Lead Exposure of Obligate Avian Scavengers in Eastern North America}

Shannon Behmke

Follow this and additional works at: https://researchrepository.wvu.edu/etd

\section{Recommended Citation}

Behmke, Shannon, "Lead Exposure of Obligate Avian Scavengers in Eastern North America" (2015). Graduate Theses, Dissertations, and Problem Reports. 5176.

https://researchrepository.wvu.edu/etd/5176

This Thesis is protected by copyright and/or related rights. It has been brought to you by the The Research Repository @ WVU with permission from the rights-holder(s). You are free to use this Thesis in any way that is permitted by the copyright and related rights legislation that applies to your use. For other uses you must obtain permission from the rights-holder(s) directly, unless additional rights are indicated by a Creative Commons license in the record and/ or on the work itself. This Thesis has been accepted for inclusion in WVU Graduate Theses, Dissertations, and Problem Reports collection by an authorized administrator of The Research Repository @ WVU. For more information, please contact researchrepository@mail.wvu.edu. 
Lead Exposure of Obligate Avian Scavengers in Eastern North America

\author{
Shannon Behmke \\ Thesis submitted to the \\ Davis College of Agriculture, Natural Resources and Design \\ at West Virginia University
}

in partial fulfillment of the requirements for the degree of

Master of Science

in

Wildlife and Fisheries Resources

Patricia Mazik, Ph.D., Co-Chair

Todd Katzner, Ph.D., Co-Chair

Jesse Fallon, DVM

Division of Forestry and Natural Resources

Morgantown, West Virginia

2015

Keywords: bone lead, chronic lead exposure, lead ammunition, lead concentration, lead sampling, liver lead, scavenger, vulture

Copyright 2015 Shannon Behmke 


\title{
ABSTRACT \\ Lead Exposure of Obligate Avian Scavengers in Eastern North America
}

\author{
Shannon Behmke
}

Lead is a toxic element within the body of living organisms. Lead poisoning cases still occur in both humans and wildlife on a regular basis in the United States. Although the harmful effects of lead within the body are well known, such as decreased IQ in children, increased renal dysfunction, hypertension, anemia, and other morbid and mortal consequences in humans and wildlife, lead continues to be used in anthropogenic activities today. Through the use of lead in ammunition and fishing sinkers, and its presence in coal-fired power plant and other industrial emissions, lead is dispersed throughout modern human and natural systems. Due to the persistence of anthropogenic lead-use, it is necessary to understand the pervasiveness of this toxin in both modern ecosystems and throughout the body of individuals.

To understand the degree to which wildlife populations are chronically exposed, we quantified lead levels within American black vultures (Coragyps atratus) and turkey vultures (Cathartes aura); two species that are useful as environmental sentinels in eastern North America. Individuals of both vulture species are known to be more resistant to the effects of lead toxicity than are many other animals. This resistance allows vultures to accumulate and harbor lead for a longer period of time than more sensitive species, thus providing us with a lifetime lead exposure history. In our study, chronic lead exposure was quantified from femur lead concentrations of 98 black vultures and 10 turkey vultures and compared to lead concentrations of liver tissues sampled from the same individuals. We found that the extent to which vultures are exposed suggests that anthropogenic lead permeates eastern North American ecosystems to a previously unrecognized degree. Discovery of an epidemic of chronic lead exposure in such widespread and common species and the failure of soft-tissue sampling to diagnose this pattern has dramatic implications for understanding modern wildlife and human health concerns.

Bone sampling, however, is difficult to replicate in living individuals. Although bone provides information regarding the depth and breadth of lead exposure, blood is most commonly sampled in live individuals. This is because phlebotomy is one of the most minimally invasive sampling techniques currently available, which makes it attractive despite the fact that blood and other soft tissues (liver, kidney) are indicative of only recent exposure to lead. However, if an individual's blood (collected by phlebotomy) or muscle (collected by biopsy) lead levels could be statistically linked to the amount of lead found within its bone, it would permit use of less invasive sampling techniques to reveal total body lead burden. Therefore, to determine if soft tissue lead concentrations have a quantifiable relationship with femur lead concentrations, we collected and analyzed multiple tissues (femur, liver, kidney, breast muscle, and thigh muscle) from the 108 black and turkey vultures mentioned above. We found that although all soft tissues were poor predictors of bone lead levels, kidney lead concentrations best predicted femur lead concentrations. These poor relationships, however, between soft tissues and bone suggest that the sampling of tissues other than bone is unlikely to provide substantial insight into the long-term lead burden that birds face. 


\section{ACKNOWLEDGEMENTS}

The people acknowledged here all contributed to the successful completion of my Master's thesis research, degree, and/or the publications that resulted from this work. My graduate committee, P. Mazik, T. Katzner, and J. Fallon, contributed greatly in providing helpful reviews of this thesis. Thank you to co-authors A. Lehner and J. Buchweitz for performing invaluable analyses for Chapter 1, to J. Fallon for teaching me to necropsy and draw blood, and to all the members of the Katzner Lab including D. Hartman, A. Duerr, T. Miller, J. Hall, M. Wheeler, A. Dennhardt, C. Slover, C. Concepcion, V. Slabe, M. Jensen, L. Stiffler, M. Paulson, and $\mathrm{M}$. Braham for providing feedback on presentations and papers throughout the years. Thank you to the Virginia State Office of USDA Wildlife Services that graciously provided us the vulture carcasses used in this project and to our funding sources that were in part provided by the Virginia Department of Game and Inland Fisheries through a Federal Aid in Wildlife Restoration grant from the U.S. Fish and Wildlife Service and the West Virginia University - Peace Corps Master's International Program (PCMI). A special thank you to T. Petty for bringing me into the PCMI program and to T. Katzner, J. Fallon, A. Duerr, E. Katzner, and G. Schmidt for assisting with necropsies. Thank you to all the graduate students, especially C. Artis, A. Dennhardt, and C. Slover, that helped me throughout the semesters overwhelmed with the simultaneous teaching of four biology labs, grading of papers, creation of tests, graduate classwork, applying for Peace Corps, writing my proposal, and performing my research, and also a great thank you to the graduate students, especially A. Watson, A. Anderson, and E. Miller, that have been helping me readjust back to the States after my Peace Corps service. Un agradecimiento grande a mi familia anfitriona en Perú que me aceptó como otra hijita/hermanita, a mis socios del Servicio Nacional de Áreas Naturales Protegidas (SERNANP-Junín), especialmente L. Barzola, R. Medrano Yanqui, R. Uribe de la Cruz, O. Damián Boldeon, D. Martínez, y W. Arias Lopez, que me aceptaron como otra trabajadora del SERNANP, y a la gente de Cuerpo de Paz (Peace Corps), especialmente D. Shoobridge, D. Crosby, K. Schammel, R. Workin, y M. Barnhart, que me proveyó apoyo y amistad durante mi servicio como Voluntaria de Cuerpo de Paz en Perú. A huge thank you to my advisor, T. Katzner, who understood the value and challenges of the PCMI program, pushed me to get everything possible out of my Master's degree, and simply said, was an exceptional graduate advisor. Finally, without the support of K. Behmke (my mom), B.

Behmke (my dad), and N. Behmke (my brother), I would not be where I am today and cannot thank my family enough for their never-ending encouragement, for all they have taught and continue to teach me, and how much their support means to me no matter where in the world I am. 


\section{TABLE OF CONTENTS}

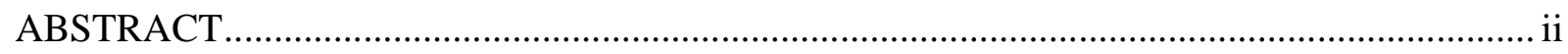

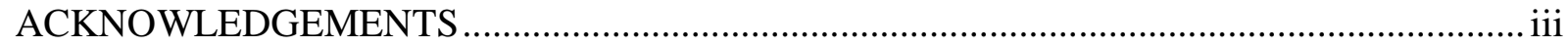

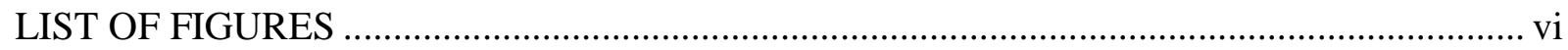

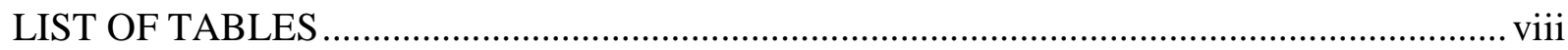

CHAPTER 1: CHRONIC LEAD EXPOSURE IS EPIDEMIC IN OBLIGATE SCAVENGER POPULATIONS IN EASTERN NORTH AMERICA …......................................................... 1

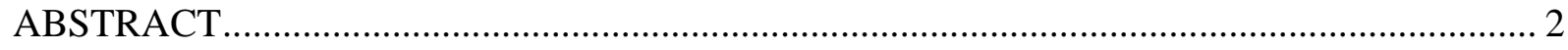

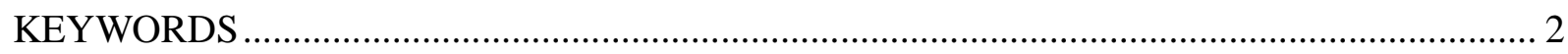

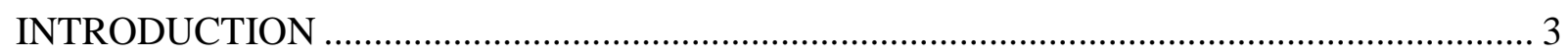

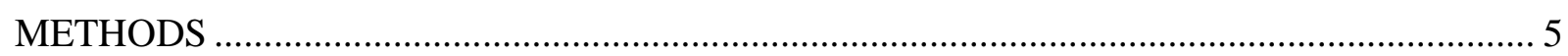

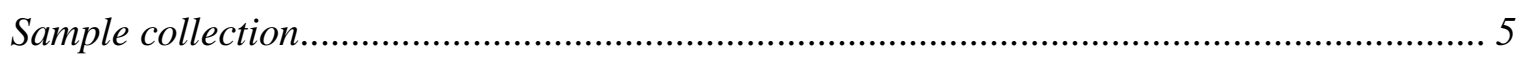

Sample preparation, lead $(\mathrm{Pb})$ concentration, and isotope ratio analysis............................... 6

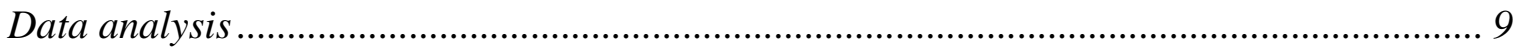

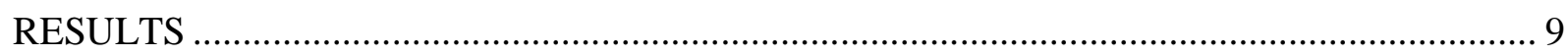

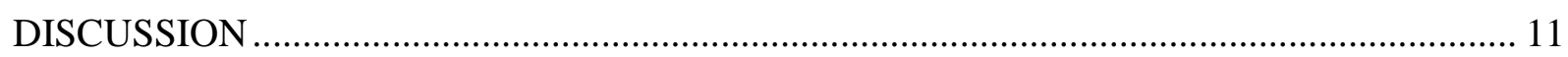

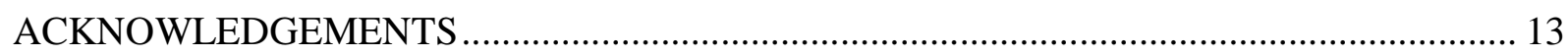

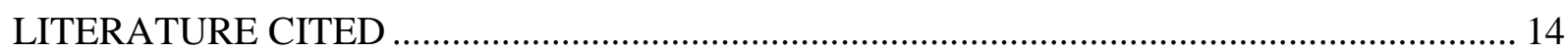

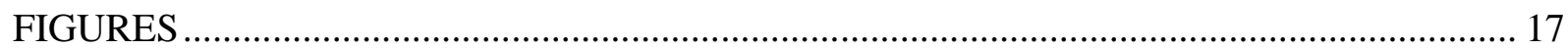

CHAPTER 2: COMMONLY USED SAMPLES FROM WILDLIFE ARE POOR PREDICTORS

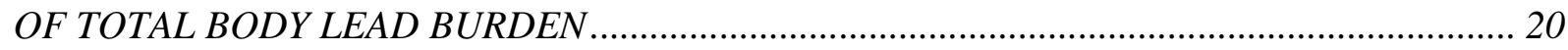

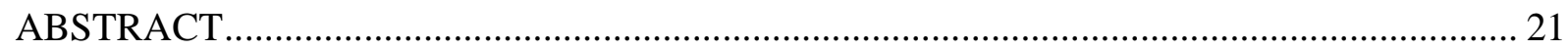

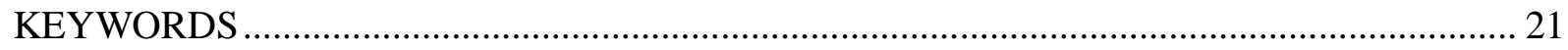

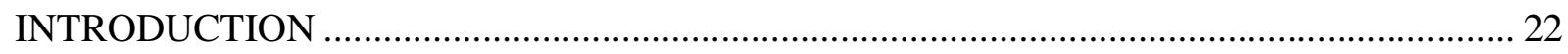

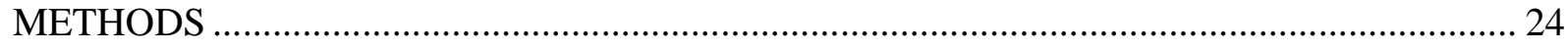

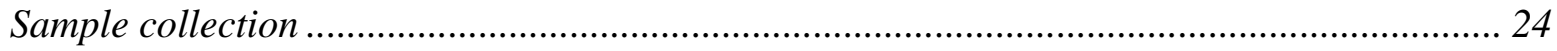

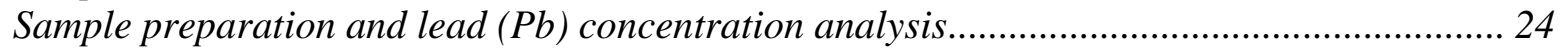

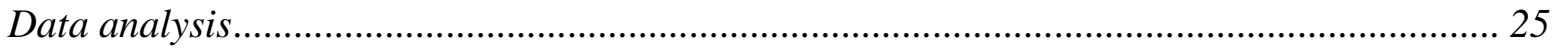

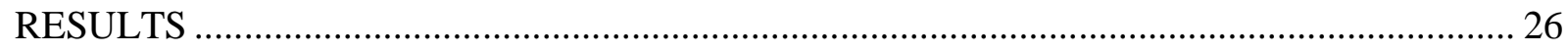

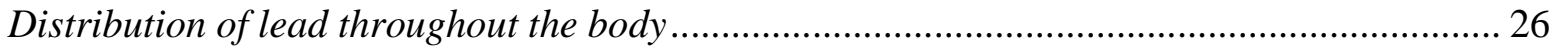

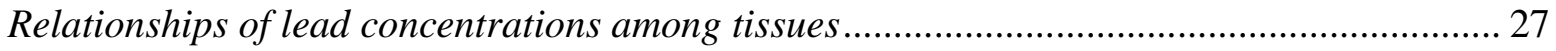

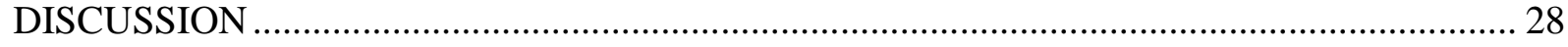




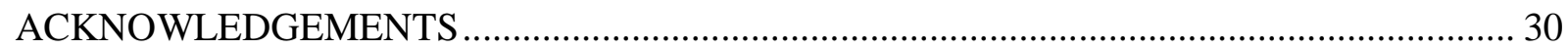

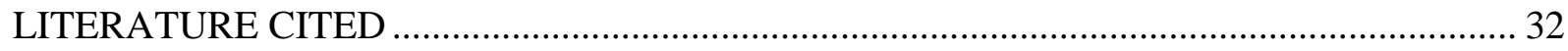

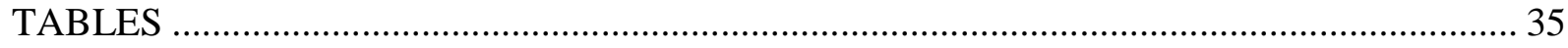

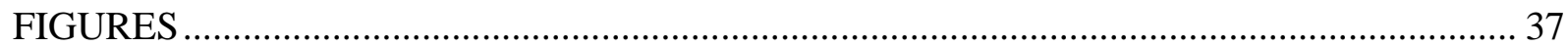




\section{LIST OF FIGURES}

Fig. 1-1. Anthropogenic lead concentrations (mg/kg) in samples from (a) femurs of black $(\mathrm{BLVU} ; \mathrm{n}=97$, outlier at $540 \mathrm{mg} / \mathrm{kg}$ excluded) and turkey $(\mathrm{TUVU} ; \mathrm{n}=10)$ vultures; and $(\mathbf{b})$ livers of black $(n=96)$ and turkey $(n=9)$ vultures.

Fig. 1-2. Relationship between anthropogenic lead levels of liver and femur in 105 vultures. Turkey vultures $(n=9)$ are indicated by closed circles, while black vultures $(n=96)$ are indicated by open circles.

Fig. 1-3. Isotope ratios $(207 \mathrm{~Pb} / 206 \mathrm{~Pb})$ of lead from vultures (this study), from California condors (Finkelstein et al., 2012), and from potential anthropogenic sources (Komárek et al., 2008). Ratios are from: (A) background lead in pre-release California condors, (B) post-release California condors, (C) lead ammunition, (D) lead-based paint from a fire tower in CA, $(\mathrm{E})$ black vultures in this study, $(\mathrm{F})$ turkey vultures in this study, (G) coal emissions, (H) zinc smelting, (I) lead smelting, and (J) leaded gasoline. The grey box shows the area of overlap between the two quantiles of the range of lead isotopes of black vultures and of potential lead sources.

Fig. 2-1. Discriminant variables of kidney, liver, and breast muscle lead concentrations in relation to femur lead levels $(\mathrm{H}=$ high, $\mathrm{M}=$ medium, and $\mathrm{L}=$ low). Femur lead levels in the "high" group of DFA averaged $50.19 \mathrm{mg} / \mathrm{kg} \pm 20.30$ (range: 30.3 104; $\mathrm{n}=23$ ), in the "medium” group averaged $25.09 \mathrm{mg} / \mathrm{kg} \pm 2.42$ (range: 20.9 $28.5 ; \mathrm{n}=17$ ), and in the "low" group averaged $12.85 \mathrm{mg} / \mathrm{kg} \pm 4.98$ (range: $4.5-$ $19.7 ; n=16)$. Kidney is most strongly negatively correlated to the first discriminant dimension of LD1, which accounts for $73.6 \%$ of variation in the data 
set. Liver and breast muscle, respectively, are positively correlated to the second discriminant dimension of LD2, which accounts for $23.4 \%$ of variation in the data set. 


\section{LIST OF TABLES}

Table 2-1. Anthropogenic lead concentrations (mg/kg) within soft tissues and bone from (a) black vultures and (b) turkey vultures collected in the U.S. state of Virginia.

Table 2-2. Relationships between soft tissue lead concentrations and femur lead concentrations of (a) black vultures and (b) turkey vultures collected in the U.S. state of Virginia. 


\section{CHAPTER 1}

CHRONIC LEAD EXPOSURE IS EPIDEMIC IN OBLIGATE SCAVENGER POPULATIONS IN EASTERN NORTH AMERICA 


\begin{abstract}
Lead is a prominent and highly toxic contaminant with important impacts to wildlife. To understand the degree to which wildlife populations are chronically exposed, we quantified lead levels within American black vultures (Coragyps atratus; BLVU) and turkey vultures (Cathartes aura; TUVU), two species that are useful as environmental sentinels in eastern North America. Every individual sampled $(\mathrm{n}=108)$ had bone lead levels indicative of chronic exposure to anthropogenic lead (BLVU: $\bar{x}=36.99 \pm 55.21 \mathrm{mg} \mathrm{Pb} / \mathrm{kg}$ tissue $( \pm \mathrm{SD})$; TUVU: $\bar{x}=23.02 \pm$ $18.77 \mathrm{mg} / \mathrm{kg}$ ). Only a few showed evidence of recent lead exposure (BLVU liver: $\bar{x}=0.78 \pm$ $0.93 \mathrm{mg} / \mathrm{kg}$; TUVU liver: $\bar{x}=0.55 \pm 0.34 \mathrm{mg} / \mathrm{kg}$ ). Isotopic ratios suggested multiple potential sources of lead including ammunition, coal-fired power plants, gasoline, and zinc smelting. Black and turkey vultures range across eastern North America, from Quebec to Florida and individuals may traverse thousands of kilometers annually. The extent to which vultures are exposed suggests that anthropogenic lead permeates eastern North American ecosystems to a previously unrecognized degree. Discovery of an epidemic of chronic lead exposure in such widespread and common species and the failure of soft-tissue sampling to diagnose this pattern has dramatic implications for understanding modern wildlife and human health concerns.
\end{abstract}

\title{
KEYWORDS
}

chronic lead exposure, lead ammunition, scavenger, vulture 


\section{INTRODUCTION}

Lead exposure increases behavioral problems and decreases the attention span and the IQ of children (Carpenter, 2001; Dietrich et al., 2001; Canfield et al., 2003). These effects are likely irreversible despite lowering blood lead levels through chelation (Carpenter, 2001). Within the U.S., lead-free paint and automobile gasoline now are mandated because of these dangers. Nevertheless, lead is still regularly used by humans in manufacturing and ammunition and is prevalent in human and natural ecosystems (Vucetich et al., 2009; Robbins et al., 2010). The quantity of spent lead shotgun shot may reach $>400,000-2$ million pellets per acre (Pain, 1991; Fry and Maurer, 2003), while estimations of annually discarded lead-tainted carcasses include 28,000 "varmint" carcasses and 36,000 big game gut piles in California (Fry and Maurer, 2003) and $>1.05$ million prairie dogs (Cynomys ludovicianus) killed with lead bullets per year in South Dakota (Huxoll, 2012). Obligate scavengers therefore are likely exposed to anthropogenic lead when foraging, and the degree to which they are exposed may be a strong indicator of the ecosystem-wide distribution of environmental lead. These analyses have substantial indirect implications for human exposure, since one of the most common vulture food sources - hunterkilled game - is also common in human diet.

High concentrations of lead in blood of birds can have a suite of detrimental physiological effects (summarized in Haig et al., 2014), including reduction in hemoglobin synthesis, decreases in bone mineralization (Locke and Thomas, 1996; Gangoso et al., 2009), oxidative insult and demyelination of nerve cells (Mateo et al., 2003). Blood lead levels have also been associated with increases in the mortality rate of the iconic and critically endangered California condor (Gymnogyps californianus; Church et al., 2006; Finkelstein et al., 2012). However, in spite of the frequency with which they are used in avian toxicology studies (i.e. liver, blood; Locke and Thomas, 1996; Snyder and Snyder, 2000; Carpenter et al., 2003; Fry and 
Maurer, 2003; Church et al., 2006; Finkelstein et al., 2012; Harmata and Restani, 2013), blood metrics are an imperfect indicator of lifetime total exposure to lead because they are responsive primarily to recent events. In fact, avian rehabilitators describe regular admission of birds with no neurological symptoms (wing drooping, flightless, listlessness; Friend et al., 1999) of lead poisoning but high blood lead levels, and admission of birds with neurological symptoms consistent with lead poisoning but low blood lead levels. This is because lead competes with and replaces calcium within the central nervous and skeletal systems (Pain et al., 2005; Finkelstein et al., 2008; Gangoso et al., 2009; Mason et al., 2014). Thus, animals chronically exposed to lead show high bone lead levels, regardless of the time since recent exposure. Likewise, blood lead levels could be indicative of either recent exposure or of long-stored lead leached from bone into blood (Ambrose et al., 2000; Mason et al., 2014). It is for this reason that bone lead metrics can be a better indicator than blood of long-term lead burden and exposure (Ambrose et al., 2000).

To evaluate the degree to which wildlife are exposed to lead and, therefore, to give insight into the extent to which anthropogenic lead pervades modern trophic systems, we evaluated chronic lead exposure of two species of obligate scavengers, the American black vulture (Coragyps atratus; hereafter black vulture) and the turkey vulture (Cathartes aura), collected in the U.S. state of Virginia. These species are two of the three avian obligate scavengers in North America (the other is the California condor whose modern range does not include eastern North America; Snyder and Snyder, 2000). East of the Mississippi River, turkey vultures are found south of $\sim 51^{\circ}$ in Quebec (Kirk and Mossman, 1998) and black vultures south of $\sim 41^{\circ}$ in Pennsylvania (Buckley, 1999). Both species aggregate in Virginia and other southern parts of their range when not breeding, and birds marked at this location have been observed 900 $\mathrm{km}$ apart (A. Duerr unpublished observations). Although black vultures are generally assumed to 
scavenge larger carcasses than turkey vultures, both species eat a wide variety of prey, including remains (including gut-piles or offal) of domestic and wild ungulates (e.g., cows, Bos taurus; sheep, Ovis aries; white-tailed deer, Odocoileus virginianus) and small- and medium-sized mammals (e.g., grey squirrel, Sciurus carolinensis; groundhog, Marmota monax) that die of natural or anthropogenic causes (Kirk and Mossman, 1998; Buckley, 1999). Individuals of both vulture species are known to be more resistant to the effects of lead toxicity than are many other animals and thus are better environmental sentinels than are species that die quickly when exposed to low concentrations of lead (i.e., these vultures can accumulate and harbor lead for a longer period of time than more sensitive species; Carpenter et al., 2003; Bravo et al., 2005).

Chronic lead exposure was evaluated by quantifying lead concentrations in femurs of culled vultures. To understand differences in chronic and recent exposure, we also quantified lead concentration in liver tissue from the same individuals. While blood is the typical medium for assessing recent exposure for live birds, liver is the preferred tissue collected from bird carcasses to understand recent toxicological events (Friend and Franson, 1999). Once harvested, tissue samples were digested in nitric acid and lead concentration measured by Inductively Coupled Plasma Mass Spectrometry (ICP-MS). We also measured lead isotope ratios (204Pb, $206 \mathrm{~Pb}, 207 \mathrm{~Pb}$, and $208 \mathrm{~Pb}$ ) of these same black and turkey vulture femur samples to determine probable sources of lead.

\section{METHODS}

\section{Sample collection}

Vultures ( $\mathrm{n}=98$ black vultures and 10 turkey vultures) were culled by the U.S. Department of Agriculture, Wildlife Services in Chesterfield County Virginia, on 26 and 27 July 2011 and between 24 April 2012 and 02 May 2012. Carcasses were frozen within 24 hours of culling. Frozen carcasses were thawed and necropsied in October 2011 and in July and August 
2012. At necropsy, we collected samples from liver, kidney, breast muscle, thigh muscle, and femur. All samples were immediately wrapped in aluminum foil, placed in a labeled plastic bag, and stored in a conventional freezer $\left(\sim-18^{\circ} \mathrm{C}\right)$ until sample preparation.

Foil-wrapped samples were thawed to room temperature for preparation. We cleaned the target tissue manually to remove traces of non-target tissue (e.g., muscle, connective tissue on bones or liver). We dissected target tissue and weighed $0.5000-0.5449 \mathrm{~g}$ (wet weight) on a digital balance (Sargent-Welch SWA 200DR). To allow comparison between samples with different masses, we used the measurement of $\mathrm{mg}$ of lead per $\mathrm{kg}$ of tissue $(\mathrm{mg} / \mathrm{kg})$. Each sample was handled with new scalpel blades and gloves and stored in a previously unused sample vial to prevent cross contamination between samples.

Sample preparation, lead $(\mathrm{Pb})$ concentration, and isotope ratio analysis

Tissue samples collected and weighed on a wet weight basis were digested in $10 \mathrm{ml}$ of $\sim 67-70 \%$ nitric acid (TraceMetal Grade, Fisher Scientific) and maintained at room temperature until analysis. Prior to analysis, samples were heated at $105^{\circ} \mathrm{C}$ for three hours and diluted to 50 $\mathrm{ml}$ with ultrapure water and then read by ICP-MS at REIC Laboratories, Beaver, WV. Method detection limits $(\mathrm{MDL})$ averaged $0.0569 \pm 0.0904$ (mean \pm SD) for black vulture samples and $0.0399 \pm 0.0008$ for turkey vulture samples.

To test the consistency of our results within tissue types, we collected new tissue samples from a small subset of the frozen tissue already analyzed. Two of the samples re-evaluated were samples whose lead concentration was within 1 standard deviation of the population mean found after the first run $($ mean $=36 \mathrm{mg} / \mathrm{kg} ;$ samples chosen $=11.8 \mathrm{mg} / \mathrm{kg}$ and $15.3 \mathrm{mg} / \mathrm{kg})$ and the third was one extreme outlier $(629 \mathrm{mg} / \mathrm{kg})$. In all cases, results were within $15 \%$ of the original measurements $(11.0 \mathrm{mg} / \mathrm{kg}, 14.0 \mathrm{mg} / \mathrm{kg}$, and $540 \mathrm{mg} / \mathrm{kg}$, respectively). In statistical analysis of 
the three tissues sampled twice, we only included the one measurement for each tissue sample that was closer to the population mean for lead concentration.

In addition to standard methodological controls implemented by the analytical lab, we submitted for analysis two types of putative blanks as controls. We prepared three samples from the femur of store-bought organically raised domestic chicken (Gallus gallus; $\mathrm{Pb}=0.766 \pm 0.19$ $\mathrm{mg} / \mathrm{kg} ; \mathrm{MDL}=0.039 \pm 0.0006$ ) and four samples of nitric acid (no tissue; $\mathrm{Pb}=0.0079 \pm 0.0028$ $\mathrm{mg} / \mathrm{L} ; \mathrm{MDL}=0.0002 \pm 0.00$ ). These represent either, at worst, typical levels of potential contamination in our sampling, or at best, actual background measures of lead in these materials.

Finally, to evaluate both lead isotope ratios in femur samples and potential lab- and instrument-specific failure points, we sent for re-analysis, 114 of our original, pre-digested vulture and control samples to a second analytical lab (Michigan State University Diagnostic Center for Population and Animal Health; MSU - DCPAH, East Lansing, MI). At this lab, NIST SRM (Standard Reference Material) 2976 mussel (0.250 g) (NIST Office of Reference Materials, Gaithersburg, MD), NIST SRM 981 common lead isotopic standard (0.250 g) (NIST Office of Reference Materials, Gaithersburg, MD), and three blank tubes were processed as quality control (QC) on lead quantitation accuracy and on background lead levels. All samples, QC materials, and blanks were brought to a mass of $10 \mathrm{~g}$ with water on a top-loading laboratory balance capable of measuring to $\pm 0.001 \mathrm{~g}$. This was done by quantitatively transferring the digested contents to a separate tube tared on the balance; the original tube was rinsed several times with Milli-Q reverse osmosis deionized water (Millipore Corporation, Billerica, MA). Dilution factors for calculation of lead concentrations were combined with the weights provided for the original samples during calculation.

Lead concentrations were determined on an Agilent 7500ce ICP-MS (Agilent 
Technologies, Santa Clara, CA) equipped with a Cetac Auto Sampler (Cetac, Omaha, NE) and MicroMist Nebulizer (Agilent). The instrument was calibrated with appropriate dilutions of Specpure $1000 \mathrm{ug} / \mathrm{mL}$ stock solutions (Alfa Aesar, Ward Hill, MA) of each element of interest according to in-house generated standard operating procedures derived from the Agilent Operator's Manual (Agilent Technologies 2004). Each quantitative analysis used a matrix matched quality control NIST SRM. Accordingly, analyses performed on bone were matched to NIST SRM 1400 (bone ash) and analyses on tissue were matched to NIST SRM 1577c (bovine liver). Digested samples were diluted in an aqueous solution of $0.05 \%(\mathrm{w} / \mathrm{v})$ ethylenediaminetetraacetic acid (EDTA), $1 \%(\mathrm{w} / \mathrm{v})$ ammonium hydroxide, $0.05 \%(\mathrm{w} / \mathrm{v})$ Triton-X 100, and 2\% (w/v) butanol prior to analysis. Listed reagents were from Sigma-Aldrich (St. Louis, MO). Lead isotopes were determined as counts per second (cps) at m/z 204, 206, 207, and 208, and $\mathrm{m} / \mathrm{z} 204$ values were adjusted for the presence of trace mercury values determined at $\mathrm{m} / \mathrm{z}$ 202 assuming a normal distribution for mercury of m/z $196(0.153 \%), 198$ (9.968\%), 199 (16.873\%), 200 (23.096\%), 201 (13.181\%), 202 (29.863\%), and 204 (6.865\%; Rosman and Taylor, 1998). M/z 207 has an explicit requirement for adjustment likely owing to an instrumentspecific mass discrimination, and it is an accepted technique to correct for such bias by using a suitable isotope standard reference material (Becker, 2005). Therefore cps values for lead were adjusted according to responses obtained from a standard of NIST SRM 981 for lead isotopes certified at m/z 204 (1.4255\%), m/z 206 (24.1442\%), m/z 207 (22.0833\%), and m/z 208 $(52.347 \%)$. This reference material was analyzed in separate nitric acid digests twenty times over a three week period to gather an average response, and application of these average responses back to the SRM provided average responses of m/z $204(1.3968 \%+/-0.0372), \mathrm{m} / \mathrm{z} 206$ (24.2802\% +/- 0.1812), m/z $207(21.9149 \%+/-0.2259)$, and m/z $208(52.4801 \%+/-0.0861)$ to 
one standard deviation, with resultant precision in terms of $\%$ RSD of $2.66 \%, 0.746 \%, 1.03 \%$, and $0.164 \%$, respectively, and accuracies of $98.0 \%, 100.6 \%, 99.2 \%$, and $100.1 \%$, respectively.

Lead concentration measurements from the two labs were well correlated $(\mathrm{R}=0.95)$. These same 114 samples included the 108 evaluated for lead isotope ratios.

\section{Data analysis}

Data analysis of lead concentrations in femur and liver were conducted on the original REIC results. To compare femur and liver concentrations among black and turkey vultures, we used a $t$-test. Statistical comparisons were performed without the femur outlier $(540 \mathrm{mg} / \mathrm{kg})$. We used a similar test to compare our lead isotope data with those from California condors (Finkelstein et al., 2012). Where appropriate, we log-transformed data to meet assumptions of the statistical tests. We correlated lead levels in femur and in liver with a Pearson correlation coefficient on the 105 birds from which both femur and liver samples were collected.

\section{RESULTS}

All 108 vultures had bone lead levels indicative of long-term lead exposure. Femur lead levels averaged $36.99 \pm 55.21 \mathrm{mg} / \mathrm{kg}( \pm \mathrm{SD}$; range: $4.5-540 ; \mathrm{n}=98$ black vultures $)$ and $23.02 \pm$ $18.77 \mathrm{mg} / \mathrm{kg}( \pm \mathrm{SD}$; range: $6.17-70 ; \mathrm{n}=10$ turkey vultures). There was no difference between the femur lead concentrations of the two vulture species (femur: $t_{10.5}=1.51, p=0.16$; Fig. $1 \mathrm{a}$ ). The range of bone lead levels we found here were, with the exception of our one outlier, broadly similar to those reported for red kites (Milvus milvus; $0-187 \mu \mathrm{g} / \mathrm{g} ; \mathrm{n}=86$; Pain et al., 2007) and Spanish imperial eagles (Aquila adalberti; 0 - $155 \mu \mathrm{g} / \mathrm{g} ; \mathrm{n}=34$; Pain et al., 2005). However, our measurements were higher than those of Egyptian vultures (Neophron percnopterus; 0 - $30 \mu \mathrm{g} / \mathrm{g}$; $\mathrm{n}=39$; Gangoso et al., 2009) and California condors (4.13 - 14.6 $\mu \mathrm{g} / \mathrm{g} ; \mathrm{n}=2$; Finkelstein et al., 2010), the second of which are regularly chelated to remove lead from their body. 
Only a few vulture samples had liver lead levels consistent with recent exposure or leaching from bone. Liver lead levels of black vultures averaged $0.78 \mathrm{mg} / \mathrm{kg} \pm 0.93( \pm \mathrm{SD}$; range: $0.12-6.17 \mathrm{mg} / \mathrm{kg} ; \mathrm{n}=96)$ and $0.55 \pm 0.34 \mathrm{mg} / \mathrm{kg}( \pm \mathrm{SD} ;$ range: $0.23-1.3 \mathrm{mg} / \mathrm{kg} ; \mathrm{n}=9)$ in turkey vultures. There was no difference between the liver lead concentrations of the two species (liver: $t_{10.5}=0.82, p=0.43$; Fig. 1b). Finally, lead levels in femur and liver were not correlated (r $=0.09$, without outlier; Fig. 2).

Average isotope ratios of $207 \mathrm{~Pb} / 206 \mathrm{~Pb}$ in femur samples were $0.8272 \pm 0.0121$ (range: $0.8055-0.8813 ; \mathrm{n}=98$ ) for black vultures and $0.8268 \pm 0.0123$ (range: $0.8121-0.8513 ; \mathrm{n}=10 ;$ Fig. 3) for turkey vultures. Isotope ratios were similar for femur samples with the highest (540 $\mathrm{mg} / \mathrm{kg} ; 207 \mathrm{~Pb} / 206 \mathrm{~Pb}=0.8557)$ and lowest $(4.5 \mathrm{mg} / \mathrm{kg} ; 207 \mathrm{~Pb} / 206 \mathrm{~Pb}=0.8341)$ lead concentrations. Isotope ratios of lead from black vultures and turkey vultures were statistically different from those of pre-release California condors (condors: $\bar{x}=0.8362 \pm 0.0056( \pm \mathrm{SD})$; range: $0.8296-0.8483 ; \mathrm{n}=22 ;$ BLVU: $t_{98}=1.99, p<0.0001 ;$ TUVU: $t_{10}=2.2, p=0.0409$; Finkelstein et al., 2012). Isotope signatures were similar to post-release (lead-ammunition exposed) California condors ( $\bar{x}=0.8284 \pm 0.0230$; range: $0.7602-0.9164 ; \mathrm{n}=110 ;$ BLVU: $t 98$ $=1.97, p=0.6086$; TUVU: $t_{10}=2.13, p=0.7217$; Finkelstein et al., 2012). Lead isotope ratios for black vultures overlapped with the upper range of published lead isotope ratios from ammunition from several different manufacturers sold in California $(\bar{x}=0.8179 \pm 0.0115 ; \mathrm{n}=$ 76 bullets, range: $0.7858-0.8706$; Finkelstein et al., 2012). Isotope ratios also overlapped to varying degrees with those reported for leaded gasoline in eastern North America $(\bar{x}=0.845 \pm$ 0.103; range: $0.719-0.962$; year $=1987$; Komárek et al., 2008), coal emissions $(\bar{x}=0.833 \pm$ 0.023; range: $0.799-0.888$; Komárek et al., 2008), and zinc smelting (Pennsylvania; $\bar{x}=0.824$ \pm 0.055 ; range: $0.817-0.829$; Komárek et al., 2008). Lead isotope ratios from lead smelting 
(Missouri; $\bar{x}=0.752 \pm 0.014$; range: $0.746-0.763$; Komárek et al., 2008) and deteriorating lead-based paint from a fire tower in California $(\bar{x}=0.8925 \pm 0.0161$; range: $0.8734-0.9148$; Finkelstein et al., 2012) were largely dissimilar to those found in eastern North American vultures.

\section{DISCUSSION}

The extent to which chronic lead exposure is epidemic in obligate scavengers in eastern North America provides important ecological insights. First, because sources of anthropogenic lead in the environment have changed dramatically with reduced use of lead in gasoline and paint (Komárek et al., 2008), the pervasiveness and chronic nature of anthropogenic lead exposure in vulture populations therefore is surprising. Furthermore, this trend would not have been evident with a sampling strategy based on standard blood or liver sampling. The fact that bone and liver lead levels were not correlated corroborates past evidence (Pain et al., 2007) that soft tissue and fluid sampling is of limited effectiveness in understanding long-term lead exposure of birds. Other studies of lead in birds have included feather sample analysis (Finkelstein et al., 2012; Harmata and Restani, 2013). Although a better measure than blood and liver of long-term exposure, even the largest birds grow their feathers over the course of $<10$ weeks, and thus lead levels in feathers are indicative only of a relatively short period of the long lifespan (>20 yrs) of these birds. Considering the kinetics of lead in an animal's body, measuring concentration in bone is likely the most effective manner to sample the long-term burden animals face from repeated lead exposure (Ambrose et al., 2000).

Second, our analysis provides key information on the potential sources of environmental lead that vultures encounter. The lead isotope ratios we measured are largely inconsistent with exposure to lead-based paint used at a fire tower in California (only one of 98 black vulture samples and zero of 10 turkey vulture samples fall in the range of paint chips that impacted 
condors in one study; Finkelstein et al., 2012) or with exposure from lead smelting operations. However, isotope ratios were nearly identical to those of post-release condors and therefore consistent with lead used in ammunition and emitted from coal-fired power plants and zinc smelting operations. In fact, coal and zinc are produced and heavily used, and recreational shooting and hunting are common in eastern North America. Future work with these and related species should consider not only the typical potential sources of lead (ammunition, paint), but also potential sources associated with their economically damaging behavior (vultures damage and ingest vehicle rubber, household waste, roofing material; Lowney, 1999).

Third, the thorough extent of exposure in these environmental sentinels suggests that anthropogenic lead permeates natural eastern North American ecosystems in a previously unrecognized manner. Because lead exposure is completely pervasive in this population, because it appears to come from multiple sources, and because it is ubiquitous in birds that range across eastern North America, it is likely that other species occupying the same space, including humans, also are exposed to this toxin, lethally and sublethally.

In the western U.S., lead poisoning is the exclusive factor holding back the recovery of the critically endangered California condor (Finkelstein et al., 2012). Although black and turkey vultures are more robust to lead poisoning than are condors (Carpenter et al., 2003) and their populations are not declining, these species play an important role as environmental sentinels in eastern North American ecosystems. Our analysis therefore suggests two important consequences for understanding human and wildlife health concerns. First, although human exposure to lead is still monitored (Cave et al., 2010; Amato et al., 2013), eastern U.S. humans at high risk (those consuming hunter-killed game or living or working near coal-fired power plants) may acquire lead with similar frequency as do these vultures. Second, the comparison between 
lead in liver and bone suggests that soft, feather, or fluid-tissue measurements typical for use in avian toxicology studies (i.e. liver, blood; Locke and Thomas, 1996; Snyder and Snyder, 2000; Carpenter et al., 2003; Fry and Maurer, 2003; Church et al., 2006; Finkelstein et al., 2012; Harmata and Restani, 2013), may be reliable indicators of only relatively short-term lead exposure. Therefore, studies that rely solely on liver, feather, or blood samples will underestimate the true pervasiveness of lead within organisms and modern ecosystems.

\section{ACKNOWLEDGEMENTS}

Vulture carcasses were graciously provided by the Virginia State Office of USDA Wildlife Services. P. Mazik and S. Barras provided helpful reviews of the manuscript and G. Schmidt and E. Katzner assisted with necropsies. This publication was completed with funds in part provided by the Virginia Department of Game and Inland Fisheries through a Federal Aid in Wildlife Restoration grant from the U.S. Fish and Wildlife Service and the West Virginia University - Peace Corps Master's International Program. Author contributions: S. Behmke and T. Katzner designed the study, S. Behmke, T. Katzner, J. Fallon, and A. Duerr collected and statistically analyzed data, A. Lehner and J. Buchweitz performed laboratory analyses, and all authors wrote the manuscript. 


\section{LITERATURE CITED}

Amato, M.S.; Magzamen, S.; Imm, P.; Havlena, J.A.; Anderson, H.A.; Kanarek, M.S.; Moore, C.F. 2013. Early lead exposure ( $<3$ years old) prospectively predicts fourth grade school suspension in Milwaukee, Wisconsin (USA). Envir. Res. 126: 60-65.

Ambrose, T.M.; Al-Lozi, M.; Scott, M.G. 2000. Bone lead concentrations assessed by in vivo Xray fluorescence. Clin. Chem. 46: 1171-1178.

Becker, J.S. 2005. Recent developments in isotope analysis by advanced mass spectrometric techniques: Plenary lecture J. Anal. At . Spectrom. 20: 1173 - 1184.

Bravo, A.; Colina, M.; Azuero, S.; Salas-A, R. 2005. Heavy metal levels in plasma and fecal material samples of the black vulture (Coragyps atratus). Revista Cientifica 15: 319-325.

Buckley, N.J. 1999. Black Vulture (Coragyps atratus), The Birds of North America Online (A. Poole, Ed.). Ithaca: Cornell Lab of Ornithology; Retrieved from the Birds of North America Online: http://bna.birds.cornell.edu/bna/species/411.

Canfield, R.L.; Henderson, C.R.; Cory-Slechta, D.A.; Cox, C.; Jusko, T.A.; Lanphear, B.P. 2003. Intellectual impairment in children with blood lead concentrations below $10 \mathrm{~g}$ per deciliter. N. Engl. J. Med. 348: 1517-26.

Carpenter, D.O. 2001. Effects of metals on the nervous system of humans and animals. Int. J. Occup. Med. Environ. Health. 14: 209-218.

Carpenter, J.W.; Pattee, O.H.; Fritts, S.H.; Rattner, B.A.; Wiemeyer, S.N.; Royle, J.A.; Smith, M.R. 2003. Experimental lead poisoning in turkey vultures (Cathartes aura). J. Wildl. Diseases 39: 96-104.

Cave, M.; Appana, S.; Patel, M.; Falkner, K.C.; McLain, C.J.; Brock, G. 2010. Polychlorinated Biphenyls, Lead, and Mercury Are Associated with Liver Disease in American Adults: NHANES 2003-2004. Envir. Health Persp. 118: 1735 - 1742.

Church, M.; Gwiazda, R.; Risebrough, R.; Sorenson, K.; Chamberlin, C.P.; Farry, S.; Heinrich, W.; Rideout, B.A.; Smith, D.R. 2006. Ammunition is the principal source of lead accumulated by California Condors reintroduced to the wild. Environ. Sci. Technol. 40: 6143-6150.

Dietrich, K.N.; Douglas, R.M.; Succop, P.A.; Berger, O.G.; Bornschein, R.L. 2001. Early exposure to lead and juvenile delinquency. Neurotoxicology 23: 511-518.

Finkelstein, M.; George, D.; Scherbinski, S.; Gwiazda, R.; Johnson, M.; Burnett, J.; Brandt, J.; Lawrey, S.; Pessier, A.P.; Clark, M.; Wynne, J.; Grantham, J.; Smith, D.R. 2010. Feather Lead Concentrations and 207Pb/206Pb Ratios Reveal Lead Exposure History of California Condors (Gymnogyps californianus). Environ. Sci. Technol. 44: 2639 - 2647. 
Finkelstein, M.; Doak, D.F.; George, D.; Burnett, J.; Brandt, J.; Church, M.; Grantham, J.; Smith, D.R. 2012. Lead poisoning and the deceptive recovery of the critically endangered California condor. PNAS 109: 11449-11454.

Finkelstein, Y.; Markowitz, M.; Rosen, J. 2008. Low-level lead-induced neurotoxicity in children: An update on central nervous system effects. Brain Research Reviews 27: 168176.

Friend, M., Franson, J.C., Eds, 1999. Field Manual of Wildlife Diseases: Chapter 42 Lead Tech. Rep. 1999-001, U.S. Geological Survey, Biological Resources Division, Madison, Wisconsin.

Fry, D.M.; Maurer, J.R. 2003. Assessment of lead contamination sources exposing California condors. Final report to the California Dept of Fish and Game, Sacramento, California.

Gangoso, L.; Alvarez-Lloret, P.; Rodriguez-Navarro, A.B.; Mateo, R.; Hiraldo, F.; Donazar, J.A. 2009. Long-term effects of lead poisoning on bone mineralization in vultures exposed to ammunition sources. Environ. Pollut. 157: 569-574.

Haig, S.M.; D’Elia, J.; Eagles-Smith, C.;, Fair, J.M., Gervais, J., Herring, G., Rivers, J.W., Schulz, J.H. 2014. The persistent problem of lead poisoning in birds from ammunition and fishing tackle. The Condor 116: 408-428.

Harmata, A.; Restani, M. 2013. Lead, mercury, selenium and other trace elements in tissues of golden eagles from southwestern Montana, USA. J. Wild. Disease 49: 114-124.

Huxoll, C. 2012. 2011 Prairie Dog Shooting Survey, South Dakota Wildlife Report No. 2012-08. South Dakota Department of Game, Fish and Parks.

Kirk, D.A.; Mossman, M.J. 1998. Turkey Vulture (Cathartes aura), The Birds of North America Online (A. Poole, Ed.). Ithaca: Cornell Lab of Ornithology; Retrieved from the Birds of North America Online: http://bna.birds.cornell.edu/bna/species/339.

Komárek, M.; Ettler, V.; Chrastný, V.; Mihaljevič, M. 2008. Lead isotopes in environmental sciences: A review. Environ. Int. 34: 562-577.

Locke, L.N.; Thomas, N.J. 1996. Lead poisoning of waterfowl and raptors. In Noninfectious Diseases of Wildlife; Fairbrother, A., Locke L.N., Hoff, G.L., Eds.; Manson, London. pp 108-117.

Lowney, M.S. 1999. Damage by black and turkey vultures in Virginia, 1990-1996. Wildl. Soc. Bull. 27: 715-719.

Mason, L.H.; Harp, J.P.; Han, D.Y. 2014. Pb neurotoxicity: Neuropsychological effects of lead toxicity. BioMed Research International, Article ID 840547, 8pp. 
Mateo, R.; Bever, W.N.; Spann, J.W.; Hoffman, D.J.; Ramis, A. 2003. Relationship between oxidative stress, pathology, and behavioral signs of lead poisoning in mallards. $J$. Toxicol. Envir. Health, A 66:1371-1389.

Pain, D. J. 1991. Lead shot densities and settlement rates in Camargue marshes, France. Biol. Cons. 57:273-286.

Pain, D.J.; Meharg, A.A., Ferrer, M.; Taggart, M.; Penteriani, V. 2005. Lead concentrations in bone and feathers of the globally threatened Spanish imperial eagle. Biol. Cons. 121: 603610.

Pain, D.J.; Carter, I.; Sainsbury, A.W.; Shore, R.F.; Eden, P.; Taggart, M.A.; Konstantinos, S.; Walker, L.A.; Meharg, A.A.; Raab, A. 2007. Lead contamination and associated disease in captive and reintroduced red kites Milvus milvus in England. Sci. Tot. Envir.376: 116 127.

Robbins, N.; Zhang, Z.-F.' Sun, J.; Ketterer, M.E.; Lalumandier, J.A.; Shulze, R.A. 2010. Childhood lead exposure and uptake in teeth in the Cleveland area during the era of leaded gasoline. Sci. Tot. Envir. 408: 4118 - 4127.

Rosman, K.J.R.; Taylor, P.D.P. 1998. Isotopic composition of the elements 1997. Pure and Appl. Chem. 70: 217-223.

Snyder N.; Snyder, H. 2000. The California Condor: A Saga of Natural History and Conservation; Academic Press.

Vucetich, J.A.; Outridge, P.M.; Peterson, R.O.; Eide, R.; Isrenn, R. 2009. Mercury, lead and lead isotope ratios in the teeth of moose (Alces alces) from Isle Royale, U.S. Upper Midwest, from 1952 to 2002. J. Environ. Monit. 11: 1352-1359. 
FIGURES

(a) femur

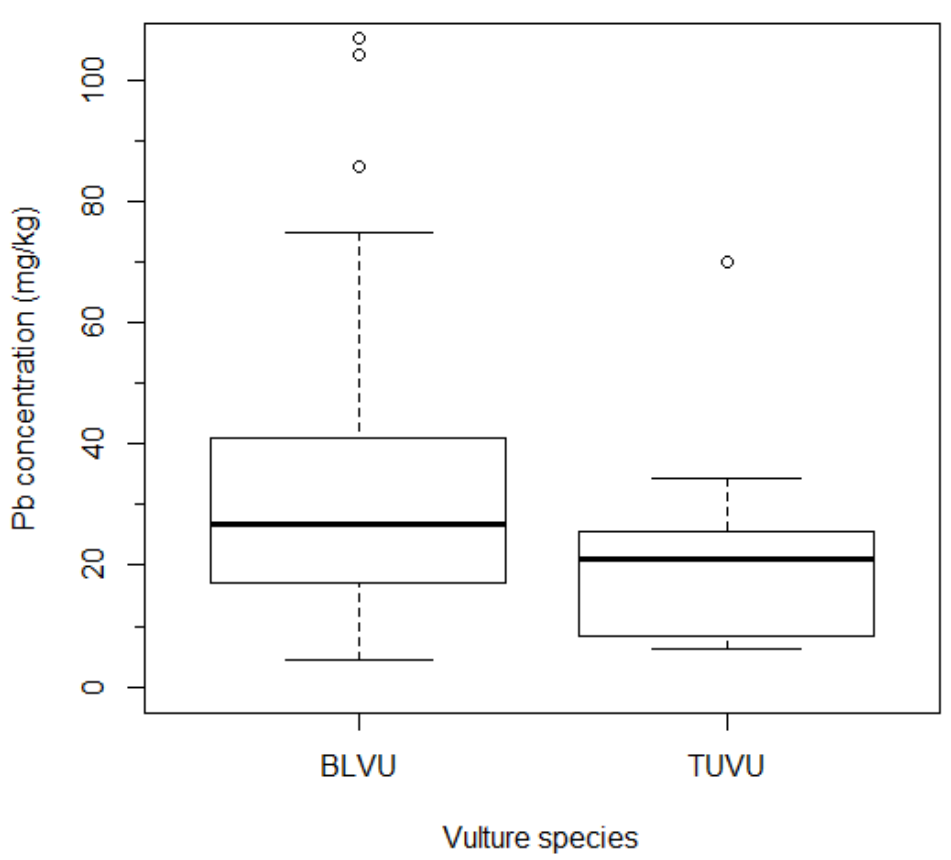

(b) liver

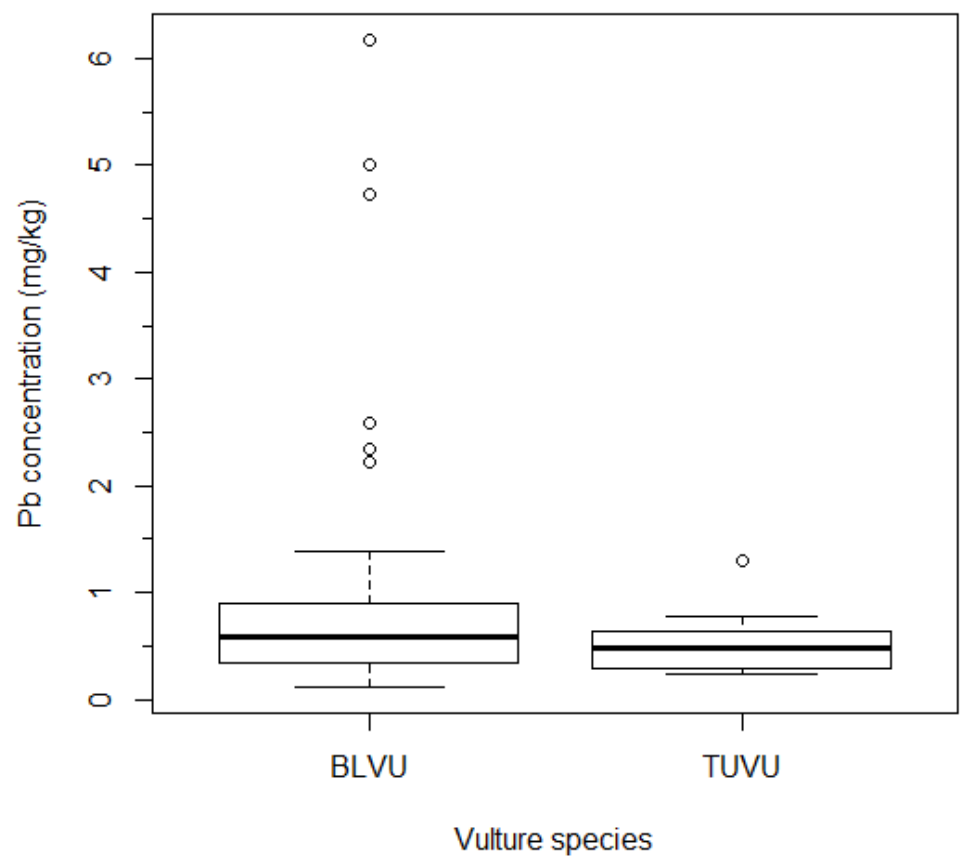

Fig. 1-1. Anthropogenic lead concentrations $(\mathrm{mg} / \mathrm{kg})$ in samples from (a) femurs of black (BLVU; $\mathrm{n}=97$, outlier at $540 \mathrm{mg} / \mathrm{kg}$ excluded) and turkey (TUVU; $\mathrm{n}=10$ ) vultures; and (b) livers of black $(n=96)$ and turkey $(n=9)$ vultures. 


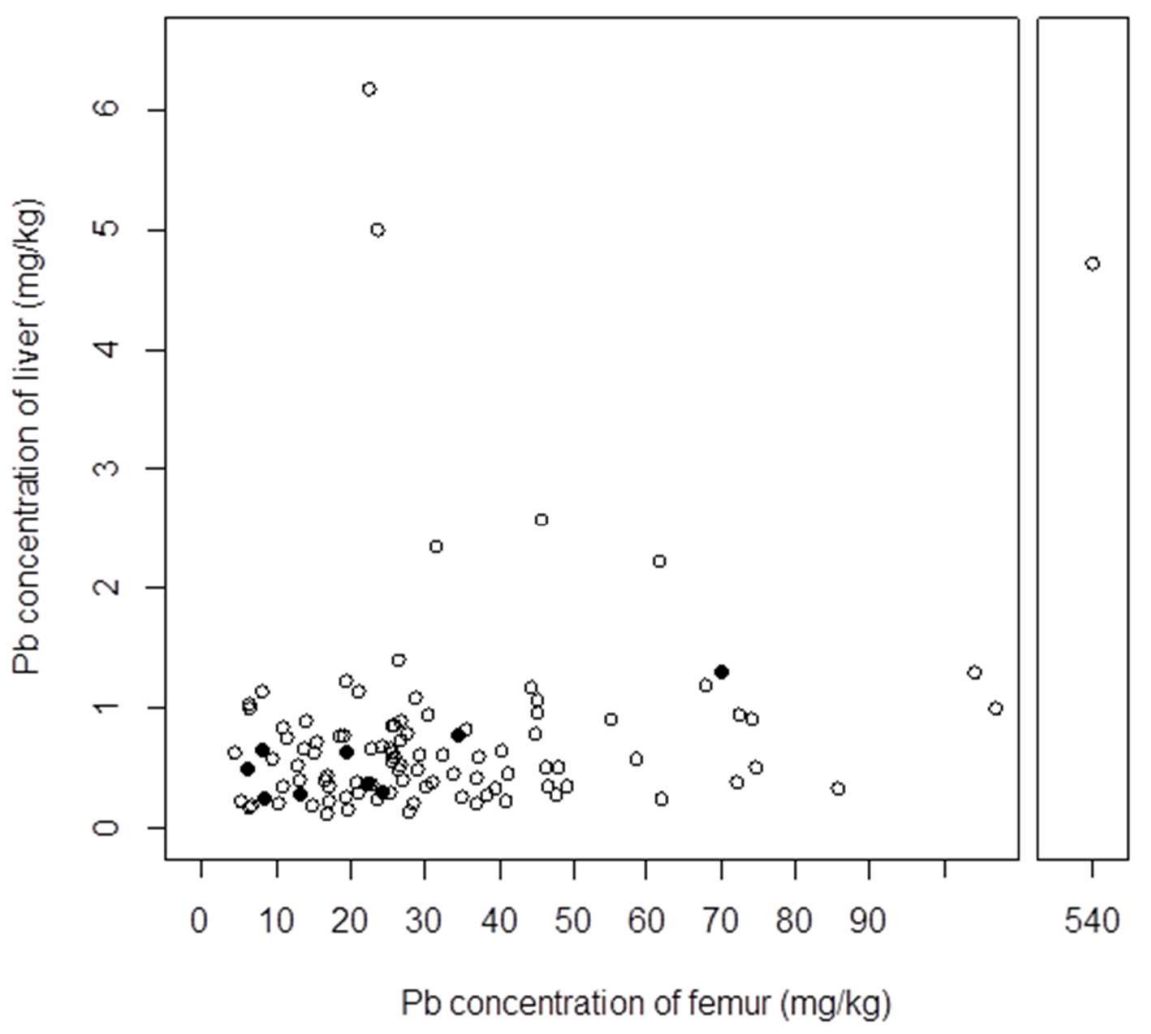

Fig. 1-2. Relationship between anthropogenic lead levels of liver and femur in 105 vultures. Turkey vultures $(n=9)$ are indicated by closed circles, while black vultures $(n=96)$ are indicated by open circles. 


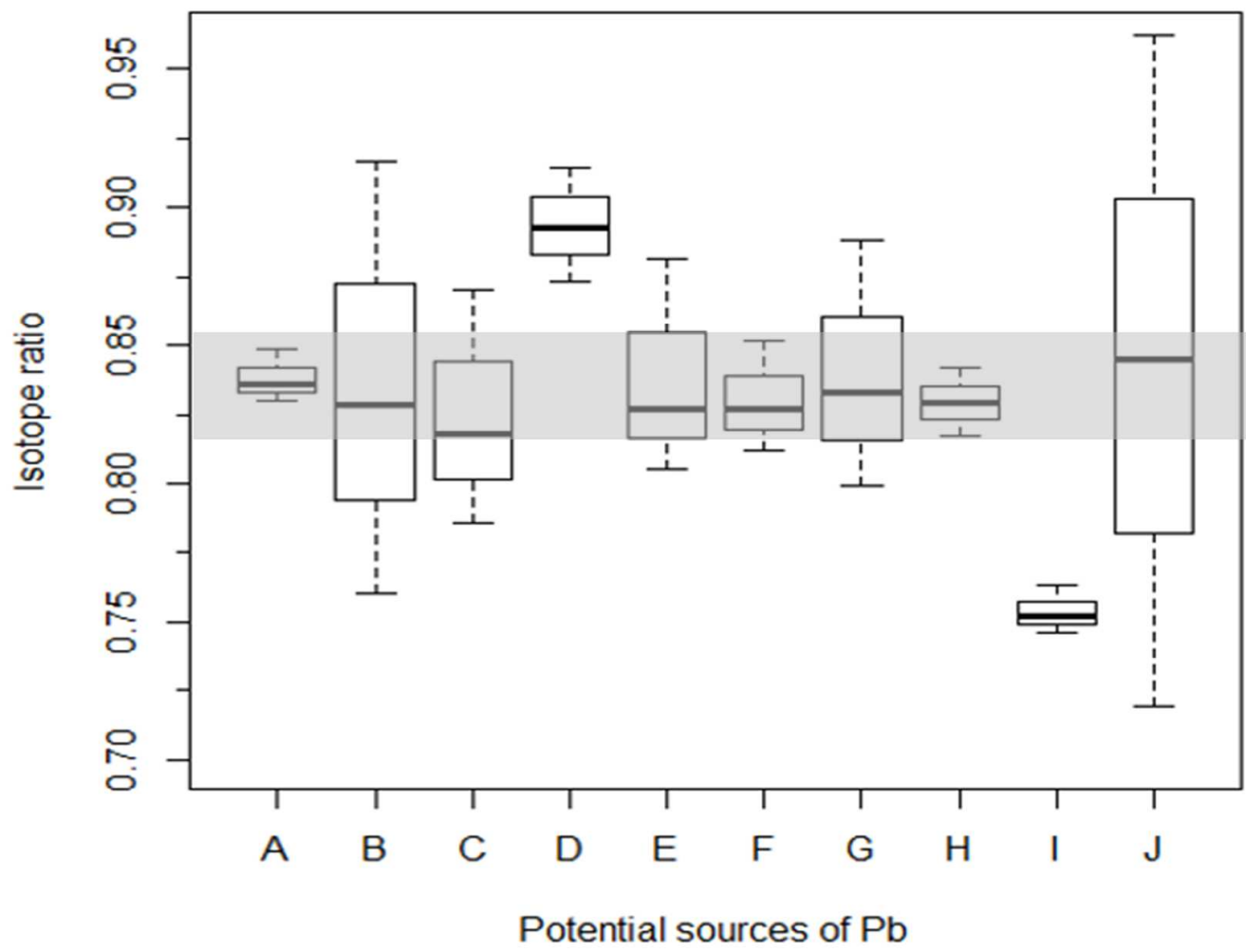

Fig. 1-3. Isotope ratios $(207 \mathrm{~Pb} / 206 \mathrm{~Pb})$ of lead from vultures (this study), from California condors (Finkelstein et al., 2012), and from potential anthropogenic sources (Komárek et al., 2008). Ratios are from: (A) background lead in pre-release California condors, (B) post-release California condors, (C) lead ammunition, (D) lead-based paint from a fire tower in CA, (E) black vultures in this study, (F) turkey vultures in this study, $(\mathrm{G})$ coal emissions, $(\mathrm{H})$ zinc smelting, (I) lead smelting, and (J) leaded gasoline. The grey box shows the area of overlap between the two quantiles of the range of lead isotopes of black vultures and of potential lead sources. 


\section{CHAPTER 2}

COMMONLY USED SAMPLES FROM WILDLIFE ARE POOR PREDICTORS OF TOTAL BODY LEAD BURDEN 


\section{ABSTRACT}

Currently, the most minimally invasive way to monitor lead in humans and wildlife is via blood samples. However, blood and other soft tissues (liver, kidney) are indicative of only recent exposure to lead and, therefore, may not provide as comprehensive a view of lead exposure as bone samples. However, if an individual's blood (collected by phlebotomy) or muscle (collected by biopsy) lead levels could be statistically linked to the amount of lead found within its bone, it would permit use of less invasive sampling techniques to reveal total body lead burden. To better understand the distribution of lead throughout the avian body, we analyzed lead concentrations from multiple tissues (femur, liver, kidney, breast muscle, and thigh muscle) from 98 black vultures (Coragyps atratus) and 10 turkey vultures (Cathartes aura). Although all soft tissues were poor predictors of bone lead levels, kidney lead concentrations best predicted femur lead concentrations $\left(\mathrm{r}^{2}=0.659\right)$. Additionally, through discriminant function analysis, we found kidney lead concentrations to be the soft tissue that best differentiated $(r=-0.98)$ among varying femur lead concentrations that were divided into the three groups of "high" $(\geq 30 \mathrm{mg} / \mathrm{kg})$, "medium" $(<30$ but $\geq 20 \mathrm{mg} / \mathrm{kg})$ and "low" $(<20 \mathrm{mg} / \mathrm{kg})$. The overall poor relationships between soft tissues and bone suggests that the sampling of tissues other than bone is unlikely to provide substantial insight into the long-term lead burden in birds. However, our research suggests that if bone samples are not available, kidney should be the soft tissue collected to better understand an individual's lead exposure history.

\section{KEYWORDS}

bone lead, kidney lead, lead concentration, lead sampling, necropsy, scavenger, vulture 


\section{INTRODUCTION}

Lead is a naturally-occurring element in the Earth's crust (Turekian et al., 1961), but is a harmful and nonessential element within the body of living organisms. The presence of any amount of lead within the body of humans or wildlife can have negative effects at both the individual and population-levels (Finkelstein et al., 1998; Finkelstein et al., 2012; Naidoo et al., 2012; Mason et al., 2014). To address human and wildlife health threats, effective monitoring of lead levels is of critical importance.

Lead in humans is associated with decreased IQ of children (Canfield et al., 2003), hypertension and renal impairment (Bautman et al., 1983), and juvenile delinquency (Dietrich et al., 2001). Elevated blood lead levels are also associated with increased societal violence (Nevin, 2007; Mielke and Zahran, 2012). Lead in wildlife is associated with decreased hemoglobin synthesis (Locke and Thomas, 1996), decreased bone mineralization (Gangoso et al., 2009), and, in birds, crop stasis and subsequent starvation (Aguilar et al., 2012). Lead poisoning also is a major factor impeding the recovery of the California condor (Gymnogyps californianus; Finkelstein et al., 2012).

Currently, the most commonly used way to monitor lead in humans and wildlife is via collection and analysis of blood samples (Locke and Thomas, 1996; Snyder and Snyder, 2000; Canfield et al., 2003; Fry and Maurer, 2003; Church et al., 2006; Finkelstein et al., 2012; Naidoo et al., 2012). Unfortunately, blood and other soft tissues (liver, kidney) are indicative of only recent exposure to lead (Hu et al., 1998; Martin et al., 2008). A slightly longer period of lead exposure can be determined through lead concentrations of keratin-based tissues (e.g., feathers and hair; Kopito et al., 1967; Pain et al., 2005). Feathers and hair reflect lead content accumulated over the period in which the tissue was formed (Tuthill, 1996; Finkelstein et al., 
2010). However, neither keratin-based tissues nor soft tissues provide a comprehensive view of the pervasiveness of lead within individuals or ecosystems (Pain et al., 2005; Gangoso et al., 2009). Some authors have suggested that the best way to accurately estimate the depth and breadth of lead exposure is via sampling bone (Hu et al., 1998; Behmke et al., 2015).

Within bone, lead ions $(\mathrm{Pb} 2+)$ compete with and replace calcium ions $(\mathrm{Ca} 2+$; Gangoso et al., 2009). Despite the occasional remobilization of bone lead back into the bloodstream, these lead ions accumulate over a lifetime within the skeletal system (Hu et al., 1998; Gangoso et al., 2009). Unfortunately, to sample bone, an individual must either be necropsied (Behmke et al., 2015), biopsied via invasive surgery (Schutz et al., 1987), or live individuals must be subjected to expensive and often logistically challenging x-ray fluorescence procedures (Hu et al., 1998). For these reasons, bone lead is not typically sampled in live individuals.

The extent of lead exposure that is revealed through bone sampling could potentially be determined if a quantifiable relationship exists among tissues within the body. If such a statistical relationship could be established, collection of other more easily sampled tissues may then provide insight into bone lead levels. This in turn, could facilitate understanding of lifetime lead exposure in living animals. For example, if an individual's blood (collected by phlebotomy) or muscle (collected by biopsy) lead levels could be statistically linked to the amount of lead found within its bone, it would permit use of less invasive sampling techniques to reveal long-term lead burden.

The overall goal of this research was to provide a baseline for potential use of minimally invasive sampling to identify lifetime lead exposure. Our study had two primary objectives. First, we aimed to better understand how lead is distributed throughout the body of avian scavengers that have not died of lead poisoning. Second, we aimed to determine if univariate or multivariate 
statistical relationships exist between lead levels in bone and other tissues. We interpreted these findings both in the context of understanding the distribution of lead throughout the avian body and also in the context of improved monitoring of lead poisoning in wildlife.

\section{METHODS}

\section{Sample collection}

Black vultures (Coragyps atratus; $\mathrm{n}=98$ ) and turkey vultures (Cathartes aura; $\mathrm{n}=10$ ) were collected in Chesterfield County Virginia in late July 2011 and in late April and early May 2012 as a part of a management program implemented by the U.S. Department of Agriculture, Wildlife Services. Carcasses were frozen within 24 hours of being euthanized. Frozen carcasses were thawed and necropsied in October 2011 and July and August 2012. During necropsy, samples were collected from liver, kidney, thigh muscle, breast muscle, and femur. All tissue samples were individually wrapped in aluminum foil, put in a labeled plastic bag, and then stored until sample preparation at approximately $-18^{\circ} \mathrm{C}$ in a conventional freezer.

Sample preparation and lead $(\mathrm{Pb})$ concentration analysis

Tissue samples were thawed to room temperature for preparation. Traces of non-target tissue (e.g., muscle, connective tissue) were removed manually from the target tissue. We weighed $0.5000-0.5449 \mathrm{~g}$ (wet weight) of the target tissue on a digital balance (Sargent-Welch SWA 200DR). To prevent cross contamination among samples, each sample was handled with new gloves and scalpel blades and was stored in a previously unused vial.

These known-weight tissue samples were then digested in $10 \mathrm{ml}$ of nitric acid (TraceMetal Grade, Fisher Scientific) and stored at room temperature until analysis. Samples were analyzed for lead concentration by Inductively Coupled Plasma Mass Spectrometry (ICPMS) at REIC Laboratories, Beaver, WV. We measured lead concentrations in mg of lead per kg 
of tissue $(\mathrm{mg} / \mathrm{kg})$ to allow for comparison among samples with different masses. We also analyzed a subset of samples (femur, primarily) at a separate lab (Diagnostic Center for Population and Animal Health, Michigan State University) for comparison. Complete details on sample preparation and lead-content analysis, as well as results of inter-lab comparisons, are provided elsewhere (Behmke Thesis Chapter 1; Behmke et al., 2015). Only lead concentration results from the first laboratory (REIC) are considered here.

\section{Data analysis}

To better understand how lead is distributed throughout the body of these avian scavengers, we summarized data on lead levels within each of the tissue samples we collected. We compared lead concentrations in each tissue type between species with a t-test (when logtransformed data were normally distributed) or with a Wilcoxon signed-rank test (when transformed data were not normally distributed).

We took a two-step approach to determine if univariate or multivariate statistical relationships exist between lead levels in bone and other tissues. First, we used regression analyses ( $\mathrm{R}$ version 3.0.3) to evaluate the potential for simple linear relationships between femur (our response variable) and four predictor variables - liver, breast muscle, thigh muscle, and kidney. We tested for normality using a Shapiro test, and, to more closely meet the assumptions of parametric statistical tests, we log-transformed data that were not normally distributed. For each regression, we only considered birds for which we had samples from both response and predictor variables. Thus, sample sizes are different for each comparison. Regressions were performed on data from both black vultures and turkey vultures.

Second, we used a discriminant function analysis (DFA; R package "MASS"; Venables and Ripley, 2002) to better understand if concentrations of lead within soft tissue - liver, breast 
muscle, and kidney - could be used as predictors in a multivariate framework to differentiate among femur lead concentrations. For this analysis we divided femur lead concentrations into groups representative of three different levels of lead exposure (high, medium, and low). "High" samples included femur lead concentrations $\geq 30 \mathrm{mg} / \mathrm{kg}$, "medium" samples were lead concentrations $<30 \mathrm{mg} / \mathrm{kg}$ but $\geq 20 \mathrm{mg} / \mathrm{kg}$, and "low" samples were those with lead concentrations $<20 \mathrm{mg} / \mathrm{kg}$. DFA was performed on the 56 black vultures from which samples of liver, breast muscle, kidney, and femur were collected.

\section{RESULTS}

\section{Distribution of lead throughout the body}

We analyzed lead levels of 98 black vultures (BLVU; one individual with femur lead level of $629 \mathrm{mg} / \mathrm{kg}$ was treated as an outlier and removed from subsequent analyses) and 10 turkey vultures (TUVU). In every black vulture sampled, femur lead concentration $(\bar{x}=$ $31.80 \mathrm{mg} / \mathrm{kg} \pm 20.42$; Table 1a) was higher than lead concentrations in every other tissue, including kidney $(0.688 \mathrm{mg} / \mathrm{kg} \pm 0.500)$, liver $(0.748 \mathrm{mg} / \mathrm{kg} \pm 0.842)$, thigh muscle $(0.152 \mathrm{mg} / \mathrm{kg} \pm$ $0.180)$, and breast muscle $(0.138 \mathrm{mg} / \mathrm{kg} \pm 0.126)$. Likewise, in every turkey vulture sampled, femur lead concentration $(\bar{x}=23.21 \mathrm{mg} / \mathrm{kg} \pm 18.77( \pm \mathrm{SD})$; Table $1 \mathrm{~b})$ was higher than lead concentrations in every other tissue, including kidney $(0.575 \mathrm{mg} / \mathrm{kg} \pm 0.320)$, liver $(0.499 \mathrm{mg} / \mathrm{kg} \pm$ $0.360)$, thigh muscle $(0.112 \mathrm{mg} / \mathrm{kg} \pm 0.045)$, and breast muscle $(0.112 \mathrm{mg} / \mathrm{kg} \pm 0.047)$.

Furthermore, lead levels in black vulture femurs in this study were on average 56 times greater than kidney (range: 10 - 210 times greater), 66 times greater than liver (range: $4-259), 369$ times greater than thigh muscle (range: 32 -1,423), and 407 times greater than breast muscle (range: $9-1,970)$. 
In 50 out of 75 black vultures we studied, kidney tissue had higher lead concentrations than did liver tissue. Kidney lead levels were on average 1.42 times greater than liver (range = $0.13-11.7$ times greater). In 55 out of 56 black vultures, kidney tissue had higher lead concentrations than did breast muscle. Kidney lead levels were on average 8.9 times greater than those in breast muscle (range: 0.58 - 52). In 58 out of 59 black vultures, liver tissue had higher lead concentrations than did breast muscle. Liver lead levels were on average 7.2 times greater than those in breast muscle (range: $0.72-51$ ). There was no statistical difference between lead levels in breast and thigh muscle $\left(t_{116.7}=-0.604, p=0.547\right)$ of black vultures. Additionally, in spite of the dramatic differences in sample size, there were no significant differences in lead levels of any tissue between the two species considered (femur: $t_{10.5}=1.51, p=0.160$; kidney: $W$ $=325.5, p=0.700$; liver: $W=572.5, p=0.290$; breast muscle: $W=259.5, p=0.859$; thigh muscle: $W=357, p=0.714)$.

Relationships of lead concentrations among tissues

Univariate regressions suggested generally weak relationships between lead levels in soft tissue and in femur of black vultures (Table 2a). Although kidney lead concentrations were the best predictor of femur lead concentrations, the relationship was still generally weak $\left(r^{2}=0.204\right)$. Concentrations of femur lead were essentially unrelated to concentrations in other tissues (liver: $r^{2}=0.015$; thigh muscle: $r^{2}=-0.008$; breast muscle: $\left.r^{2}=-0.007\right)$.

In spite of the small sample size, between-tissue relationships within turkey vultures were similar to those of black vultures (Table 2b). Once again, kidney lead concentrations were the best predictor of femur lead concentrations $\left(r^{2}=0.659\right)$. Also, concentrations of femur lead were once again essentially unrelated to concentrations in other tissues (liver: $\mathrm{r}^{2}=0.152$; thigh muscle: $r^{2}=-0.113$; breast muscle: $r^{2}=-0.143$ ) 
Multivariate statistical analysis (DFA) performed better than univariate analyses in describing relationships among soft tissue and femur lead concentrations (Figure 1). The first discriminant dimension resulting from our DFA accounted for $73.6 \%$ of the variation in the dataset, and was most strongly negatively correlated with kidney lead levels $(r=-0.98)$. The second discriminant dimension accounted for $26.4 \%$ of the variation in the dataset, and was positively correlated with liver $(\mathrm{r}=0.80)$ and, to a lesser degree, breast muscle $(\mathrm{r}=0.61)$.

\section{DISCUSSION}

Lead is widely and disparately distributed throughout the bodies of the vultures we studied. The organism-wide lead distribution that we report here provides insight for future sampling to better monitor lead exposure in wildlife. Our analysis, however, did not identify any strong statistical relationships between femur and the soft tissues we sampled that would allow us to predict bone lead levels.

Univariate relationships between lead levels in soft tissue and those in bone were generally poor. This finding suggests that sampling of tissues other than bone is unlikely to provide substantial insight into the long-term lead burden in birds. This conclusion is further supported by the dramatically lower lead concentrations that we found in kidney, liver, and muscle tissue than in bone. These tissue lead concentrations generally conform to previous toxicological and physiological studies that demonstrate that the skeletal system is the ultimate reservoir for lead (Hu et al., 1998; Gangoso et al., 2009).

Our work suggests that if bone samples are not available, kidney is a better tissue than liver to better understand lead accumulation within the body. Oddly, liver is the tissue most commonly sampled during necropsy to determine the degree of lead poisoning in birds (Blus et al., 1995; Friend \& Franson, 1999). Liver measurements, however, poorly reflect total body 
burden of lead and may also poorly reflect recent lead exposure. This is likely attributed to the physiology of the organ and its role, or lack thereof, in the detoxification of lead from the body. For example, since lead is an element, which by definition cannot be metabolized, and a main function of the liver is to metabolize molecules by oxidation or reduction (Doneley, 2004), lead usually is not eliminated from the bloodstream via this organ. Furthermore, although lead is a toxin that causes deleterious effects within the body, it is often transported and stored throughout the body as if it were a calcium ion (Gangoso et al., 2009). This mistaken identity most likely permits lead ions to follow the sequestration process designed for calcium ions, where it is drawn into the bones (Gangoso et al., 2009), used by the nervous system (Braet et al., 2004), and filtered through the kidneys (Bushinsky and Monk, 1998). Given that lead ions can replace calcium in physiological reactions, it makes sense that the kidneys play a larger role than liver in the filtration and removal of blood-borne lead.

Despite the role that kidneys play in the pathophysiology of lead, kidney tissue alone was still a weak predictor of femur lead levels. Rather than interpreting soft-tissue measurements, monitoring long-term lead exposure of birds appears to be best conducted via bone sampling. Although sampling bone of live wildlife is often complicated and logistically challenging, new technologies are being developed. A useful mechanism that may facilitate the process of bone sampling in live individuals to better monitor environmental lead exposure may be the recently developed portable x-ray fluorescence (XRF) machines (Nie et al., 2011; Little et al., 2014).

Until these technologies improve, a potentially useful and simple next step for lead testing of live individuals may be sampling excrement. This follows from human medicine because urine is often collected and analyzed to monitor the effects of chelation in lead-poisoned people (Bautman et al., 1983). Our study suggests application to wildlife because we found the 
two best soft tissues to use in monitoring lead exposure are organs of the excretory and digestive systems (kidney and liver, respectively). Excretory samples are also convenient because they are reasonably straightforward to collect. Future studies should determine how lead levels in excrement of live birds correlate to lead levels in bone, kidney, and liver of euthanized individuals.

Our work provides valuable information regarding organism-wide patterns of lead sequestration in raptors that have not died of lead poisoning. In particular, our results show that lead levels in bones are dramatically more useful in describing lead exposure than are lead levels in any other tissue. Our analysis also illustrates how determination of lead poisoning depends dramatically on the tissue sampled. If we had only sampled liver or kidney tissue, it is extremely unlikely that we would have understood the degree to which lead exposure is pervasive within these populations of obligate avian scavengers (Behmke et al., 2015). Determining the pervasiveness of environmental toxins in wildlife, however, presents special challenges. This is especially the case for species for which hundreds of dead individuals are not readily available. Therefore, our work also points out the importance of identifying new mechanisms for sampling and new ways to understand the long-term lead burden carried in live, as opposed to harvested, wildlife.

\section{ACKNOWLEDGEMENTS}

Vulture carcasses were graciously provided by the Virginia State Office of USDA Wildlife Services. Thank you to J. Fallon, A. Duerr, T. Katzner, G. Schmidt, and E. Katzner who assisted with necropsies and special thanks to P. Mazik, T. Katzner, and J. Fallon who provided helpful reviews of the manuscript. This publication was completed with funds in part provided by the Virginia Department of Game and Inland Fisheries through a Federal Aid in Wildlife 
Restoration grant from the U.S. Fish and Wildlife Service and the West Virginia University Peace Corps Master's International Program. Author contributions: S. Behmke and T. Katzner designed the study and collected and statistically analyzed data. All authors wrote the manuscript. 


\section{LITERATURE CITED}

Aguilar, R.F., Yoshicedo, J.N., Parish, C.N. 2012. Ingluviotomy tube placement for lead-induced crop stasis in the California condor (Gymnogyps californianus). J. Avian Med. Surg. 26, 176-181. doi:10.1647/2010-029R2.1

Batuman, V., Landy, E., Maesaka, J., Wedeen, R. 1983. Contribution of lead to hypertension with renal impairment. N. Engl. J. Med. 309, 17-21.

Behmke, S., Fallon, J., Duerr, A.E., Lehner, A., Buchweitz, J., Katzner, T. 2015. Chronic lead exposure is epidemic in obligate scavenger populations in eastern North America. Environ. Int. 79, 51-55. doi:10.1016/j.envint.2015.03.010

Blus, L.J., Henny, C.J., Hoffman, D.J., Grove, R.A. 1995. Accumulation and effects of lead and cadmium on waterfowl and passerines in northern Idaho. Environ. Pollut. 89, 311-318. doi:10.1007/BF00119436

Braet, K., Cabooter, L., Paemeleire, K., Leybaert, L. 2004. Calcium signal communication in the central nervous system. Biol. Cell 96, 79-91. doi:10.1016/j.biolcel.2003.10.007

Bushinsky, D.A., Monk, R.D. 1998. Calcium. Lancet 352, 305-311. doi:10.1016/s01406736(97)12331-5

Canfield, R.L., Henderson, C.R., Cory-Slechta, D.A., Cox, C., Jusko, T.A., Lanphear, B.P. 2003. Intellectual impairment in children with blood lead concentrations below $10 \mathrm{~g}$ per deciliter. N. Engl. J. Med. 348: 1517-26.

Church, M., Gwiazda, R., Risebrough, R., Sorenson, K., Chamberlin, C.P., Farry, S., Heinrich, W., Rideout, B.A., Smith, D.R. 2006. Ammunition is the principal source of lead accumulated by California Condors reintroduced to the wild. Environ. Sci. Technol. 40: 6143-6150.

Dietrich, K.N., Ris, M.D., Succop, P.A., Berger, O.G., Bornschein, R.L. 2001. Early exposure to lead and juvenile delinquency. Neurotoxicol. Teratol. 23, 511-518.

Doneley, B. 2004. Treating liver disease in the avian patient. Semin. Avian Exot. Pet Med. 13, 815. doi:10.1053/S1055-937X(03)00053-7

Finkelstein, M.E., Doak, D.F., George, D., Burnett, J., Brandt, J., Church, M., Grantham, J., Smith, D.R. 2012. Lead poisoning and the deceptive recovery of the critically endangered California condor. Proc. Natl. Acad. Sci. 109, 11449-11454. doi:10.1073/pnas.1203141109

Finkelstein, M., George, D., Scherbinski, S., Gwiazda, R., Johnson, M., Burnett, J., Brandt, J., Lawrey, S., Pessier, A.P., Clark, M., Wynne, J., Grantham, J., Smith, D.R. 2010. Feather lead concentrations and $207 \mathrm{~Pb} / 206 \mathrm{~Pb}$ ratios reveal lead exposure history of California condors (Gymnogyps californianus). Environ. Sci. Technol. 44: 2639 - 2647. 
Finkelstein, Y., Markowitz, M.E., Rosen, J.F. 1998. Low-level lead-induced neurotoxicity in children: An update on central nervous system effects. Brain Res. Rev. 27, 168-176. doi:10.1016/S0165-0173(98)00011-3

Friend, M., Franson, J.C., Eds, 1999. Field Manual of Wildlife Diseases: Chapter 42 Lead Tech. Rep. 1999-001, U.S. Geological Survey, Biological Resources Division, Madison, Wisconsin.

Fry, D.M. Maurer, J.R. 2003. Assessment of lead contamination sources exposing California condors. Final report to the California Dept of Fish and Game, Sacramento, California.

Gangoso, L., Álvarez-Lloret, P., Rodríguez-Navarro, A.B., Mateo, R., Hiraldo, F., Donázar, J.A. 2009. Long-term effects of lead poisoning on bone mineralization in vultures exposed to ammunition sources. Environ. Pollut. 157, 569-574. doi:10.1016/j.envpol.2008.09.015

Hu, H., Rabinowitz, M., Smith, D. 1998. Bone Lead as a Biological Marker in Epidemiologic Studies of Chronic Toxicity: Conceptual Paradigms. Environ. Health Perspect. 106, 1-8.

Kopito, L., Byers, R., Schwachman, H. 1967. Lead in hair of children with chronic lead poisoning. N. Engl. J. Med. 276, 949-953.

Little, N.C., Florey, V., Molina, I., Owsley, D.W., Speakman, R.J. 2014. Measuring heavy metal content in bone using portable X-ray fluorescence. Open J. Archaeom. 2, 19-21. doi:10.4081/arc.2014.5257

Locke, L.N., Thomas, N.J. 1996. Lead poisoning of waterfowl and raptors. In Noninfectious Diseases of Wildlife; Fairbrother, A., Locke L.N., Hoff, G.L., Eds.; Manson, London. pp 108-117.

Martin, P.A., Campbell, D., Hughes, K., McDaniel, T. 2008. Lead in the tissues of terrestrial raptors in southern Ontario, Canada, 1995-2001. Sci. Total Environ. 391, 96-103. doi:10.1016/j.scitotenv.2007.11.012

Mason, L.H., Harp, J.P., Han, D.Y. 2014. Pb neurotoxicity: Neuropsychological effects of lead toxicity. Biomed Res. Int. 2014, 1-8.

Mielke, H.W., Zahran, S. 2012. The urban rise and fall of air lead $(\mathrm{Pb})$ and the latent surge and retreat of societal violence. Environ. Int. 43, 48-55. doi:10.1016/j.envint.2012.03.005

Naidoo, V., Wolter, K., Espie, I., Kotze, A. 2012. Lead toxicity: consequences and interventions in an intensively managed (Gyps coprotheres) vulture colony. J. Zoo Wildl. Med. 43, 573578. doi:10.1638/2012-0060R.1

Nevin, R. 2007. Understanding international crime trends: The legacy of preschool lead exposure. Environ. Res. 104, 315-336. doi:10.1016/j.envres.2007.02.008 
Nie, L., Sanchez, S., Newton, K., Grodzins, L., Cleveland, R., Weisskopf, M. 2011. In vivo quantification of lead in bone with a portable X-ray fluorescence (XRF) system:

Methodology and feasibility. Phys Med Biol. 56, N39-N51.

doi:10.1016/j.biotechadv.2011.08.021.Secreted

Pain, D.J., Meharg, A.A., Ferrer, M., Taggart, M., Penteriani, V. 2005. Lead concentrations in bones and feathers of the globally threatened Spanish imperial eagle. Biol. Conserv. 121, 603-610. doi:10.1016/j.biocon.2004.06.012

Schütz, A., Skerfving, S., Christoffersson, J.O., Ahlgren, L., Mattson, S. 1987. Lead in vertebral bone biopsies from active and retired lead workers. Arch. Environ. Health 42, 340-346. doi:10.1080/00039896.1987.9934356

Snyder N.; Snyder, H. 2000. The California Condor: A Saga of Natural History and Conservation; Academic Press.

Turekian, K.K., Wedepohl, K.H. 1961. Distribution of the elements in some major units of the Earth's crust. Geol. Soc. Am. Bull. 72, 175-192.

Tuthill, R.W. 1996. Hair lead levels related to children's classroom attention-deficit behavior. Arch. Environ. Health 51, 214-220. doi:10.1080/00039896.1996.9936018

Venables, W. N., Ripley, B. D. 2002 Modern Applied Statistics with S. Fourth Edition. Springer, New York. ISBN 0-387-95457-0 


\section{TABLES}

Table 2-1. Anthropogenic lead concentrations ( $\mathrm{mg} / \mathrm{kg})$ within soft tissues and bone from (a) black vultures and (b) turkey vultures collected in the U.S. state of Virginia.

(a)

\begin{tabular}{lccccc}
\hline & femur & kidney & liver & thigh & breast \\
\hline $\mathrm{n}$ & 97 & 75 & 95 & 77 & 60 \\
mean & 31.8 & 0.688 & 0.748 & 0.152 & 0.138 \\
median & 26.8 & 0.529 & 0.576 & 0.088 & 0.093 \\
min & 4.50 & 0.130 & 0.120 & 0.042 & 0.010 \\
$\max$ & 107 & 3.15 & 6.17 & 1.23 & 0.615 \\
\hline
\end{tabular}

(b)

\begin{tabular}{lccccc}
\hline & femur & kidney & liver & thigh & breast \\
\hline $\mathrm{n}$ & 10 & 8 & 10 & 10 & 9 \\
mean & 23.2 & 0.575 & 0.499 & 0.112 & 0.112 \\
median & 21.0 & 0.530 & 0.426 & 0.129 & 0.114 \\
min & 6.17 & 0.137 & 0.010 & 0.053 & 0.060 \\
$\max$ & 70.0 & 1.12 & 1.30 & 0.177 & 0.192 \\
\hline
\end{tabular}


Table 2-2. Relationships between soft tissue lead concentrations and femur lead concentrations of (a) black vultures and (b) turkey vultures collected in the U.S. state of Virginia.

(a)

\begin{tabular}{lcccc}
\hline \multicolumn{1}{c}{ Tissue regression } & p-value \& significance & Intercept & Slope & Adjusted $\mathrm{r}^{2}$ \\
\hline femur (y) vs. kidney (x) & $<0.0001 * * *$ & 3.569 & 0.532 & 0.204 \\
femur (y) vs. liver (x) & 0.123 & 3.347 & 0.146 & 0.015 \\
femur (y) vs. thigh muscle (x) & 0.517 & 3.421 & 0.067 & -0.008 \\
femur (y) vs. breast muscle (x) & 0.438 & 3.483 & 0.079 & -0.007 \\
\hline
\end{tabular}

(b)

\begin{tabular}{lcccc}
\hline \multicolumn{1}{c}{ Tissue regression } & p-value \& significance & Intercept & Slope & Adjusted $\mathrm{r}^{2}$ \\
\hline femur (y) vs. kidney (x) & $0.0089 * *$ & 4.047 & -1.980 & 0.659 \\
femur (y) vs. liver (x) & 0.145 & 2.381 & 1.024 & 0.152 \\
femur (y) vs. thigh muscle (x) & 0.780 & 2.704 & 1.691 & -0.113 \\
femur (y) vs. breast muscle (x) & 0.989 & 2.873 & 0.092 & -0.143 \\
\hline
\end{tabular}




\section{FIGURES}

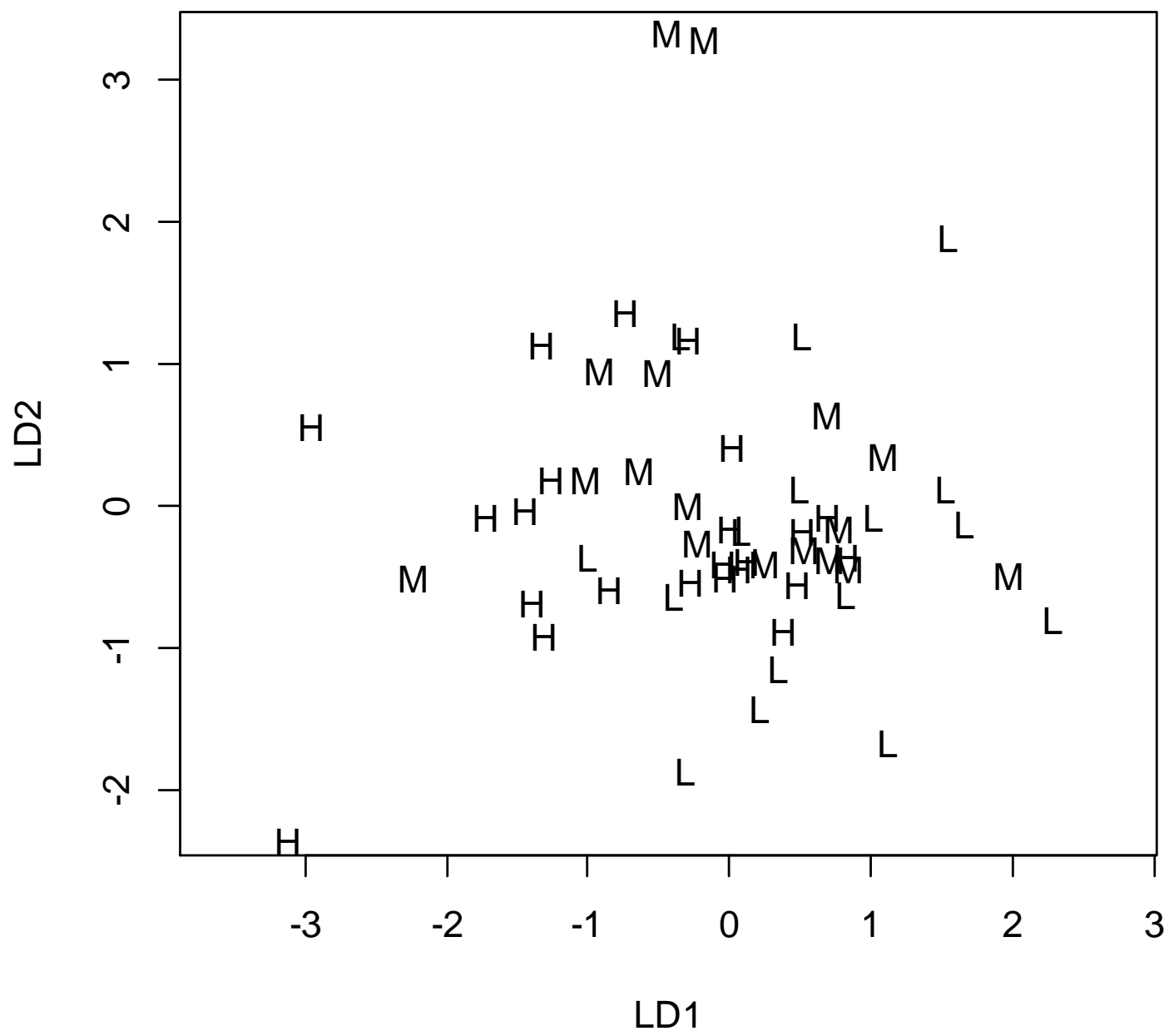

Fig. 2-1. Discriminant variables of kidney, liver, and breast muscle lead concentrations in relation to femur lead levels $(\mathrm{H}=$ high, $\mathrm{M}=$ medium, and $\mathrm{L}=$ low). Femur lead levels in the "high" group of DFA averaged $50.19 \mathrm{mg} / \mathrm{kg} \pm$ 20.30 (range: $30.3-104 ; \mathrm{n}=23$ ), in the "medium" group averaged $25.09 \mathrm{mg} / \mathrm{kg}$ \pm 2.42 (range: $20.9-28.5 ; \mathrm{n}=17$ ), and in the "low" group averaged $12.85 \mathrm{mg} / \mathrm{kg}$ \pm 4.98 (range: $4.5-19.7 ; \mathrm{n}=16$ ). Kidney is most strongly negatively correlated to the first discriminant dimension of LD1, which accounts for $73.6 \%$ of variation in the data set. Liver and breast muscle, respectively, are positively correlated to the second discriminant dimension of LD2, which accounts for $23.4 \%$ of variation in the data set. 